\title{
PEGARUH SALURAN DISTRIBUSI TERHADAP VOLUME PENJUALAN (Studi pada PT Graha Kerindo Utama Kediri)
}

\author{
Disusun Oleh : \\ Nurul Farida' \\ Dosen Fakultas Ekonomi Universitas Islam Balitar \\ Email.nurulfarida27@yahoo.co.id
}

\begin{abstract}
In streamlining of product and service flow from produsers to consumers one of the most important or should not be ignored is distribution, in an effort to reach the purpose and target of company in marketing every companies do distribution. The main purpose of company in essence is same, that is increasing the volume of sale so the provit will be increasing without ignoring consumers satisfaction. This research using the quantitavestatistics with "Analis Korelasi Sederhana" often called "Korelasi Pearson (Person Product Moment), it purpose for knowing the effect of distribution on volume of sales. Based on the result obtained by correlation $r=0,987$ and do experiment of " $t$ " with the result $t b=19.42$ so it can be concluded based on $t$ tabe, $t$ greater than $t$ in table $a=1 \%(19.42>$ 3,169), so Ho was rejected. It mean between distribution with volume of sales is very influential and significant.
\end{abstract}

Key-words : Distribution, volume of sales

\section{Pendahuluan}

Ditengah perkembangan perekonomian yang serba modern ini berbagai bidang dapat di masuki perusahaan atau industri akibat perubahan yang cepat dalam selera, teknologi dan persaingan.Untuk menghadapi persaingan, maka perusahaan perlu melaksanakan usaha kegiatan pemasaran dengan menggunakan saluran distribusi yang tepat sehingga tujuan dapat dicapai. Tujuan utama perusahaanpada intinya sama, yaitu dapat meningkatkan volume penjualan sehingga laba yang dihasilkan akan terus meningkat, namun tanpa meninggalkan kepuasan yang dirasakan oleh konsumen. Perkembangan dunia usaha dewasa ini mengalami peningkatan yang cukup pesat.Peningkatan itu disebabkan karena kebutuhan manusia yang semakin komplek. Sehingga hal ini mendorong perusahaan untuk memenuhi akan permintaan suatu kebutuhan. Dalam menenuhi permintaan tersebut, perusahaan harus menghadapi persaingan yang ketat baik untuk perusahaan yang memproduksi produk sejenis maupun yang berbeda sama sekali. Untuk dapat menarik konsumen melakukan pembelian, maka perusahaan harus menerapkan suatu strategi pemasaran yang tepat dengan kondisi pasar 
yangdihadapi. Keberhasilan strategi pemasaran dipengaruhi oleh beberapa faktor diantaranya yaitu produk, harga, promosi, dan saluran distribusi(Saladin ,djaslim:2006).

Dalam rangka mempelancar arus barang dan jasa dari pihak produsen kekonsumen maka salah satu faktor yang sangat penting atau tidak boleh diabaikan adalah saluran distribusi. Perusahaan menekan pentingnya saluran distribusi mengingat bahwa cara ini dapat digunakan dan berfungsi sebagai tolak ukur kemampuan pemasaran di berbagai unit pemasaran tersebut. Dalam usaha mencapai tujuan dan sasaran perusahaan di bidang pemasaran,setiap perusahaan melakukan kegiatan penyaluran atau distribusi. Penyaluran merupakan kegiatan penyampaian produk sampai ke tangan pemakai atau konsumen pada waktu yang tepat. Saluran distribusi adalah sekelompok organisasi yang saling tergantung yang terlibat dalam proses yang memungkinkan suatu produk atau jasa tersedia bagi penggunaan atau konsumsi oleh konsumen atau pengguna industrial Banyaknya cara yang dapat dipakai untuk menyalurkan barang dan jasa kepada konsumen salah satunya adalah dengan menggunakan jasa saluran distribusi

Distribusi adalah bagian dari bauran pemasaran (Produk, Harga, Distribusi, dan Promosi) yang memegang peranan cukup penting, karena Distribusi berperan dalam pengalokasian barang agar mudah dijangkau oleh konsumen.Dimana distribusi itu sendiri terdiri dari Saluran Distribusi dan Distribusi Fisik.

Sedangkan pengetian distribusi menurut Nirwan Sembiring (1991:39) "Distribusi adalah penyaluran barang dari suatu tempat ketempat lainnya atau dari produsen ke konsumen untuk dimanfaatkan."

MenurutBasu Swastha dan Irawan (2005:285),adalah sebagai berikut:"Saluran distribusi adalah suatu jalur yang dilalui oleh arus barangbarang dari produsen ke perantara dan akhirnya sampai pada konsumen."

Dari definisi terebut diatas menurut Basu Swastha dan Irawan (2005:286), dapat diketahui adanya beberapa unsur penting yaitu :

1. Saluran distribusi merupakan sekelompok lembaga yang ada diberbagai lembaga yang mengadakan kerjasama untuk mencapai suatu tujuan.

2. Karena anggota-anggota kelompok terdiri atas beberapa pedagang dan beberapa agen, maka ada sebagian yang ikut memperoleh nama dan sebagian yang lain tidak. Tidak perlu bagi setiap saluran distribusi untuk menggunakan sebuah agen, tetapi pada prinsipnya setiap saluran distribusi harus memiliki seorang pedagang. Alasannya adalah bahwa hanya pedagang saja yang dianggap tepat sebagai pemilik untuk memindahkan barang. Dalam hal ini, distribusi fisik merupakan kegiatan penting.

3. Tujuan dari saluran distribusi adalah untuk mencapai pasar-pasar tertentu. Jadi pasar merupakan tujuan akhir dari kegiatan saluran distribusi.

4. Saluran distribusi melaksanakan dua kegiatan penting untuk mencapai tujuan, yaitu mengadakan penggolongan produk dan 
mendistribusikannya. Penggolongan produk menunjukan jumlah produk dari berbagai keperluan produk yang dapat memberikan kepuasan kepada pasar. Jadi, barang (mungkin juga jasa) merupakan bagian dari penggolongan produk.

Untuk lebih jelasnya, berikut dikemukakan definisi penjualan menurut Basu Swastha dan Irawan (2005:406)“Penjualan adalah transaksi jual beli atau pemindahan hak milik secara komersial atas barang dan jasa yang pada prinsipnya melibatkan dua pihak yaitu penjual dan pembeli."

Selanjutnya menurut Winardi (1998:350) mendefinisikan penjualan sebagai berikut :"Volume penjualan adalah hasil penjualan yang dinyatakan dalam bentuk kuantitatif, fiscal, atau volume. 'Berdasarkan pengertian tersebut dapat diketahui bahwa volume penjualan merupakan hasil keseluruhan jumlah barang yang telah terjual oleh perusahaan pada waktu tertentu atau periode tertentu dalam kegiatan pemasaran yang dilaksanakan oleh perusahaan mengenai hasil-hasil produksinya.

\section{Rumusan Masalah}

Berdasarkanlatar belakang yang diuraian di atas, makamasalah penelitian dapat dirumuskan sebagaiberikut:"SeberapajauhpengaruhSaluran DistribusiTerhadapVolume penjualan terhadap produk Tissue pada perusahaan PT GrahaKerindoUtama Kediri?

\section{TujuanPenelitian}

Berdasarkan rumusan masalah yang telah dikemukakan, maka tujuan penelitian ini adalah : "Untuk mengetahui seberapa jauh pengaruh Saluran Distribusi terhadap peningkatan volume penjualan pada perusahaan PT GrahaKerindoUtama Kediri”.

\section{Batasan Masalah}

Upaya menghindari adanya salah tafsir dan perbedaan pengertian sertalebih memperjelas permasalahan yang dibahas, maka sangat perlu ada batasan masalah dalam penelitian ini, dengan melihat judul di atas penulis membatasimasalah berkisar pada pengaruh saluran distribusi terhadap peningkatan volume penjualan pada perusahaan PT GrahaKerindoUtama Kediri.

\section{Metodologi Penelitian Jenis Penelitian}

Dalam penelitian ini peneliti menggunakan pendekatan statistik kuantitatif dengan Analisis Korelasi sederhana atau sering disebut dengan Korelasi Pearson (Pearson Product Moment) tujuannya yaitu untuk mengetahui pengaruh saluran distribusi terhadap volume penjualan.

\section{Populasi dan Sampel}


Dalam penelitian ilmiah masalah obyek penelitian adalah merupakan faktor utama yang harus dinyatakan sebelum penelitian ini dilakukan. Populasi adalah keseluruhan objek penelitian (Arikunto suharsimi,2006,130) Obyek penelitian ini yang menjadi populasi adalah volume penjualan dari agen-agen distributor perusahaan PT GrahaKerindoUtama Kediri. berhubung populasi 12 periode diambil semua, maka sampel ditiadakan (sampel penuh).

\section{Metode Pengumpulan Data}

Supaya dapat dianalisa dan diintepretasikan dengan baik maka perlu data yang valid dan hasilnya nanti dapat diharapkan merupakan penelitianyang mengandung suatu kebenaran yang ilmiah.Dalam penelitian peneliti mencari data-data yang diperlukan, yaitu data yang diperoleh langsung dariperusahaan PT GrahaKerindoUtama Kediri.

\section{Sumber Data}

1. Data Primer

Penelitian lapangan ini dilakukan untuk mendapatkan data-data yang berhubungan dengan objek penelitian secara langsung di lapangan

2. Data Sekunder

Yaitu dengan cara mempelajari, meneliti, mengkaji serta menelaah literatur-literatur yang ada kaitanya dengan masalah yang diteliti.

Teknik Pengumpulan Data

Adapun teknik pengumpulan data yang penulis gunakan adalah sebagai berikut:

1. Interview (wawancara), proses pengumpulan data yang dilakukan dengan cara tanya jawab sambil bertatap muka secara langsung dengan pimpinan perusahaan atau instansi dan Karyawan.

2. Observasi,

Yaitu pengumpulan data yang dilakukan dengan cara melakukan pengamatan langsung pada obyek penelitian serta melakukan pencatatan secara sistematis mengenai hal-hal yang diteliti.

3. Studi Pustaka yaitu dengan menggunakan buku-buku dan literatur-literatur untuk mendukung penelitian agar lebih kuat

4. Dokumentasi YaituCara pengumpulan data dengan mencatat dokumen yang ada di perusahaan sesuai dengan obyek yang diteliti.

\section{Variabel Penelitian}

Dalam penelitian ini ada dua variabelyaitu :

1. Variabel Bebas $(X)=$ Saluran distribusi

Dimana saluran distribusi diukur dengan menggunakan jumlah outlet atau toko yang berperan dalam pendistribusian

2. Variabel Terikat $(Y)=$ Volume Penjualan 
Di ukur dengan jumlah volume penjualan perbulan.

\section{Devinisi Konseptual Variabel}

1. Saluran Distribusi $(X)$

Saluran distribusi di definisikan yaitu suatu jalur yang dilalui oleh arus barang-barang dari produsen ke perantara dan akhirnya sampai pada konsumen (Basu Swastha dan Irawan (2005:285)).

2. Volume Penjualan (Y)

Volume penjualan didefinisikan yaituhasil penjualan yang dinyatakan dalam bentuk kuantitatif, fiscal, atau volume( Winardi (1998:350))

\section{Teknik Analisa Data}

Pada teknik analisis data, penulis menggunakan analisis Korelasi sederhana atau sering disebut dengan Korelasi Pearson (Pearson Product Moment) tujuannya untuk mengetahui pengaruh saluran distribusi terhadap peningkatan volume penjualan tissue pada perusahaan PT GrahaKerindoUtama Kediri.

Adapun untuk menghitung koefisiensi korelasi digunakan rumus :

Sedangkan untuk menguji hipotesis yang menyatakan ada pengaruh variabel saluran distribusi terhadap peningaktan volume penjulan perusahaan PT GrahaKerindoUtama Kediri dilakukan uji t, dengan rumus :

\section{Hasil Penelitian}

\section{Analisis Data}

Tabel 2

Data Penjualan PT GrahaKerindoUtama Kediri

\begin{tabular}{llllll}
\hline $\mathbf{N}$ & $\mathbf{X}$ & $\mathbf{Y}$ & $\mathbf{X}^{2}$ & $\mathbf{Y}^{2}$ & $\mathbf{X} . \mathbf{Y}$ \\
1 & 70 & 890 & 4,900 & 792,100 & 62,300 \\
2 & 78 & 920 & 6,084 & 846,400 & 71,760 \\
3 & 80 & 950 & 6,400 & 902,500 & 76,000 \\
4 & 85 & 990 & 7,225 & 980,100 & 84,150 \\
5 & 87 & 1,000 & 7,569 & $1,000,000$ & 87,000 \\
6 & 89 & 1,010 & 7,921 & $1,020,100$ & 89,890 \\
7 & 90 & 1,030 & 8,100 & $1,060,900$ & 92,700 \\
8 & 80 & 940 & 6,400 & 883,600 & 75,200 \\
9 & 88 & 1,010 & 7,744 & $1,020,100$ & 88,880 \\
10 & 91 & 1,030 & 8,281 & $1,060,900$ & 93,730
\end{tabular}




\begin{tabular}{llllll}
11 & 94 & $\mathbf{1 , 0 5 0}$ & $\mathbf{8 , 8 3 6}$ & $\mathbf{1 , 1 0 2 , 5 0 0}$ & 98,700 \\
12 & 100 & $\mathbf{1 , 1 2 0}$ & 10,000 & $\mathbf{1 , 2 5 4 , 4 0 0}$ & $\mathbf{1 1 2 , 0 0 0}$ \\
& $\mathbf{1 , 0 3 2}$ & $\mathbf{1 1 , 9 4 0}$ & $\mathbf{8 9 , 4 6 0}$ & $\mathbf{1 1 , 9 2 3 , 6 0 0}$ & $\mathbf{1 , 0 3 2 , 3 1}$ \\
\hline
\end{tabular}

Sumber Data :Data diolah

$$
\begin{aligned}
& r_{X Y}=\frac{n \cdot \sum X Y-\left(\sum X\right) \cdot\left(\sum Y\right)}{\sqrt{\left\{n \sum X^{2}-\left(\sum X\right)^{2}\right\}\left\{n \sum Y^{2}-\left(\sum Y\right)^{2}\right.}} \\
& r_{X Y}=\frac{n \cdot \sum X Y-\left(\sum X\right) \cdot\left(\sum Y\right)}{\sqrt{\left\{n \sum X^{2}-\left(\sum X\right)^{2}\right\}\left\{n \sum Y^{2}-\left(\sum Y\right)^{2}\right\}}} \\
& r=\frac{12 \cdot 1,032,310-1,032 \cdot 11,940}{\sqrt{ }\left(12 \cdot 89,460-(1,32)^{2}\right) \cdot(12 \cdot 11 \cdot 923 \cdot 600-} \\
& \left.(11,940)^{2}\right) \\
& \text { 12. } 1,032,310-1,032 \cdot 11,940 \\
& \checkmark\left(12.89,460-(1,32)^{2}\right) \text {. (12. } 11.923 .600- \\
& \left.(11,940)^{2}\right) \\
& 12,387,520-12,322,080 \\
& \checkmark(1,073,520-1,065,124) \quad \text {. } \quad(143,083,200 \quad- \\
& 142,563,600) \\
& \frac{65.640}{\sqrt{ }(8496.519600)} \\
& \frac{65.640}{\sqrt{ } 4414521600} \\
& 65.640 \\
& 66441,86 \\
& r=0,987
\end{aligned}
$$

\section{Uji t}

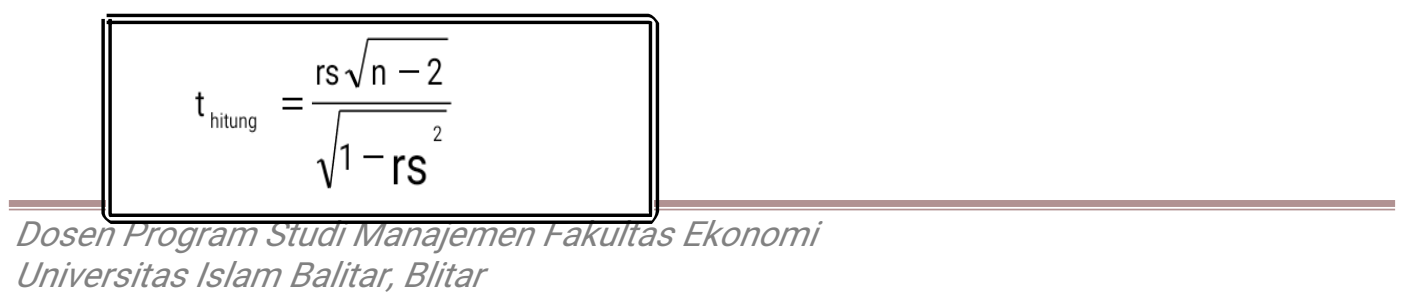




$$
\begin{aligned}
& t=\frac{0,987 \sqrt{ } 10}{\sqrt{ } 1-0,987^{2}} \\
& t=\frac{0,987 \cdot 3,1623}{\sqrt{ } 1-0,974169} \\
& t=\frac{3.1211901}{\sqrt{ } 0,025831} \\
& t=\frac{3.1211901}{0.16072025} \\
& t=19,42
\end{aligned}
$$

Berdasarkan nilai tabel ternyata t hitung lebih besar daripada t table pada $a=1 \%(19.42>3,169)$ maka $H_{\circ}$ ditolak artinya antara saluran distribusa dengan volume penjualan sangat berpengaruh dan sangat signifikan.

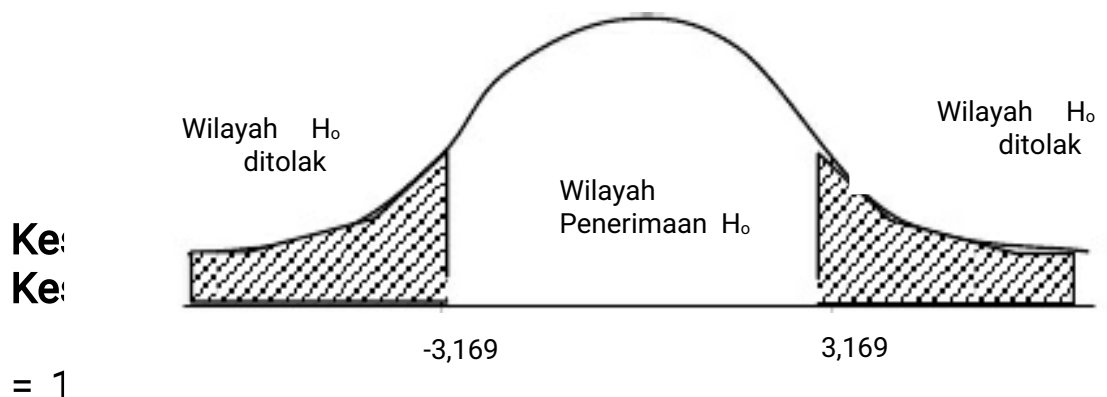

$=1$

antala saluidlı uisllinusi uellyalı vuluille pejualalı aud llunullyall yally sangat signifikan dan positif.maka dapat disimpulkan bahwa saluran distribusi sangat berpengaruh terhadap peningkatan volume penjualan dimana semakin banyak saluran distribusi yang digunakan perusahaan maka akan semakin meningkat volume penjualan perusahaan yang man akan berpengaruh terhadap peningkatan keuntungan.

\section{Saran}

Untuk menghadapi persaingan yang semakin ketat, teknologi semakin maju dan dimana selera konsumen yang selalu berubah-ubah, maka perusahaan perlu memperluas pemasaran dengan memperbanyak saluran distribusi dan perusahaan lebih meningkatkan pelayanan distribusi agar produk cepat dan tepat di tangan konsumen sehingga tujuan dapat dicapai.

\section{Daftar Pustaka}

Alma, Buchari, 2007, Manajemen Pemasaran dan Pemasaran Jasa, 


\section{Bandung: $\quad$ CV. Alfabeta}

Basu Swasta, 2000, Manajemen Penjualan, edisi keempat, bagian penerbit akademi keuangan dan binis, Yogyakarta

Basu Swasta DH dan Irawan, 2003, Manajemen Pemasaran Modern,Edisi

Kedua, $\quad$ Cetakan Kesebelas, Yogyakarta: Liberty Offset

Dr. Anwar Sanusi, SE.,M.Si, Metode Penelitian Praktis Untuk IImu Sosial dan Ekonomi, Buntara Media, Malang 2003.

H. Saladin Djaslim, 1996, Unsur-Unsur Inti Pemasaran,Edisi Ke Limah PuluhSatu,Yogyakarta: Gramedia

Marom, Chairul, 1990, Sistem Akuntansi Perusahaan Dagang, Edisi Ke Empat, Salemba Empat, Jakarta.

Saladin, Djaslim, 2006 ,Manajemen Pemasaran, Edisi Keempat, Bandung:Linda Karya

Stanton, 1996, Fundamental Of Marketing, Cetakan Ke Enam, Yogyakarta:liberty Offset

Sembiring, Nirwan, 1991, Macam-Macam Distribusi, , Cetakan Ke Tiga

puluh Sembilan,Bandung: Gramedia

Saladin, 2007, Marketing Management, Edisi KeTiga, Bandung: Gramedia 